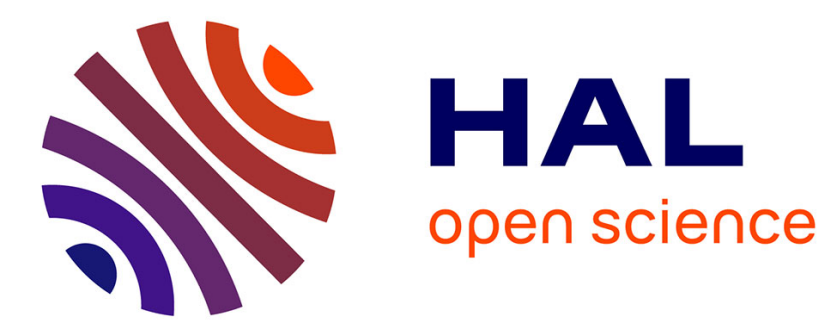

\title{
The white lady of Brandberg, South-West Africa, her companions and her guards
}

\author{
Henri Breuil
}

\section{To cite this version:}

Henri Breuil. The white lady of Brandberg, South-West Africa, her companions and her guards. South African Archaeological Bulletin, 1948, III (9), pp.1-13. halshs-00700720

\section{HAL Id: halshs-00700720 \\ https://shs.hal.science/halshs-00700720}

Submitted on 23 May 2012

HAL is a multi-disciplinary open access archive for the deposit and dissemination of scientific research documents, whether they are published or not. The documents may come from teaching and research institutions in France or abroad, or from public or private research centers.
L'archive ouverte pluridisciplinaire HAL, est destinée au dépôt et à la diffusion de documents scientifiques de niveau recherche, publiés ou non, émanant des établissements d'enseignement et de recherche français ou étrangers, des laboratoires publics ou privés. 
The Presidential Address is built about a new and fascinating clue to ancient Africa's story.

\title{
The White Lady of Brandberg, South-West Africa, Her Companions and Her Guards.
}

\author{
AbBe Heinr BreurL, President of the Society
}

The Brandberg is a neo-granitic mountain standing on a foundation of basalt, indurated schist and quartzite, and is situated. 70 miles from Cape Cross where the Portuguese ships of Diego Cam anchored in 1485. These mariners erected one of their stone crosses, making no effort to explore the interior and seeing none of the inhabitants. The Brandberg lies 250 miles by car northwest of Windhoek, the capital of South-West Africa, near the edge of the high subdesertic plateau of meagre grass plains savannas, with no permanent waterholes, in a region where there is gold, alluvial tin and copper.

Vast Old Palaeolithic and Middle Stone Age stations lie along the base of this range in the parts where there are sheets of granitic gravels, indurated schist and white vein quartz. This shows that the present desertic conditions have not always existed. The late Middle Stone Age and Late Stone Age sites are even more frequent below the granite rock shelters near the temporary or seasonal waterholes, round which there are sometimes abundant remains of Hottentot pottery.

\section{THE ROAD TO THE SHELTERS}

The Brandberg is cut across by a certain number of ravines containing many shelters, the chief ravine being the Tsisab (Leopard's) Ravine. This is deeply cut and runs NE- SW, coming out on to a triangular gravel plain forming. several terraces covered with sand and red earth, scattered sparsely with bushes and smail trees, spaced as if in an orchard. Walking up the bed of the river, which is dry except in the rainy season, after about a mile and a half, at a place where the river has cut a narrow passage for itself through a quartzitic barrier, there are many hut circles, and the surface is strewn with the chips of late Middle Stone Age tools. In the ravine, which beyond this rises gradually, the gravel terraces dominate the thalweg and contain pebbles-chiefly indurated schist - or granite boulders. Granitic rock-shelters edge it and remains of a good many hut circles with heavy Smithfield A tools. The hut floors are strewn with flakes and tools of quartz of weathered indurated shale either Middle Stone Age or Smithfield A. About three miles from the wide entrance of the ravine, a real avalanche of huge granite boulders covers the slopes to a great height, forming hundreds of rock-shelters. In this part of the ravine the stream had to cut its bed through a colossal rock-slide, due to a mass of granite having crashed down in Pliocene times; the smooth rock surface on the left marks the way it came.

At the exit from this chaos of boulders and in the part where the river cuts its bed, are several permanent waterholes with running water of excellent quality

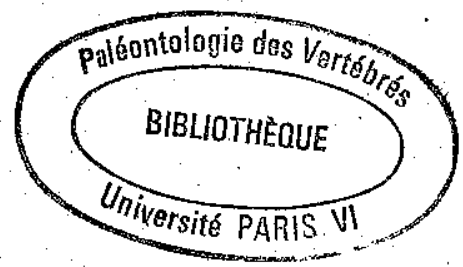


- the only permanent drinking place for 50 miles round. ${ }^{1}$ At this point the river bed divides into two branches, that on the right bank forming a waterfall, which when we were there was bone dry but must be considerable in the rainy season. ${ }^{2}$.

Between the two branches which rejoin rather less than a mile higher up, rises a very steep "island", formed of an accumulation of gigantic boulders. Ther are many rock-shelters on it and between the immense blocks run narrow passage or ways, connecting wide spaces often cleared of their boulders, like sports grounds. The whole gives a picturesque impression as of some "enchanted city"; the many rock-shelters seen there are full of ash deposit rich in stone tools. ${ }^{3}$

It is here in this "enchanted city" that Lieutenant Jochmann discovered several rock paintings before 1910 (re-visited later about 1920 by Reinhar Maack), which our capable guides Dr. Martin and Dr. Scherz rediscovered during our stay in these parts, whilst I was copying the paintings in the principal shelter. They also explored the rocks on the left bank facing the island, finding several shelters there, only one of which was copied by Fraulein Weyersberg before 1929. We do not know if the ravine upstream (which goes on for several miles) also contains painted rocks and habitation. sites; former explorers have said nothing about them.

Herr R. Maack, who during his topographical work as a surveyor stayed several times in the Brandberg, is the discoverer of the shelter with the "White Lady", which Lieut. Jochmann had not seen.

Ascending the river bed, on arrival at the point where the stream divides in two, the rocky mass on the right bank is like a: steep headland, overlooking the junction of the two arms and the waterfall already mentioned. Instead of passing it, one must climb up this spur and go through a steep narrow passage leading upwards between it and the mass of rocks covering the adjoining slopes In this way a fairly wide horizontal terrace is reached, like a balcony above the right branch of the stream; here, there are several shelters but without paintings.

To find the shelter of the "Lady" one must not remain on this terrace, but directly the top of the narrow climibing passage is reached, turn sharply to the left between two rocks which almost touch. The one on the right is hollowed on its northwest face looking down on the valley, forming an alcove like the quarter of a was the goal of our journey.

A rock on the left has protected it almost completely from atmospheric injury The sun never strikes directly on the frescoes, but only on the ground and foot of the wall, which has flaked off. But it strikes the ground and this lower zone, almost all day from sunrise to sunset, and roasts the backs of any visitors. ${ }^{4}$

The floor was ash, full of workshop chips of indurated shale and had probably been disturbed by Maack for, judging from a shallow excavation made by Dr. Martin, its contents were in disorder - white quartz and black schist chips being jumbled together. Some few ostrich egg-shell beads were found here as well as in other soundings on the island.

\section{THE WHITE LADY SHELTE}

Maack's copies, in the possession of the Archaeological Survey, attracted my attention in 1929 when I was at Johannesburg. Another version of the same copies, equally clumsy drawings, was reproduced by Hugo Obermaier and Herbert Kïhn in Bushman Art in 1932. Fraulein Weyersberg was sent, before 1929, to South-West Africa by Frobenius; she copied only a certain number of the figures. Her work (though very superior to the former eopies) was not very well produced in the Matsimu Dsangara: of Frobenius. She was the first to see that the White Lady had a face. I suppose that difficulties of lodging and food in the Brandberg did not allow of her doing better. She was the first to publish, I think from a simple retouched photograph, the very remarkable fresco in the "Girls' School" rock shelter, on the left bank, which Dr. Scherz found for us.

When Mrs. Alice Bowler-Kelley eame back to South Africa in 193\%, I pressed her to go to the Brandberg and take some photographs, so that I could judge of the importance of the site. She obtained the help of Dr. E. Scherz of Windhoek, a clever photographer, and brought me back the photographs asked for. The approach and arrival of war prevented me from seeing enlarged proofs of these before 1942 in the Archaeological Survey, Johannesburg. It was then that I say that the Lady's face was Mediterranean. An independent examination of this photograph by my assistant, Miss M. E. Boyle, ended in the same verdict, though she said "Cretan". A better enlargement was then made and shown to FieldMarshal Smuts, who promised to send us there as soon as circumstances permitted; and so it was that we could devote ten days to copying this shelter, and rapidly visit those re-discovered by Drs. Martin and Scherz whilst I was working. Except for the shelters on the right bank; of which I copied the chief panels, I had not time to draw the others, some of which Dr. Scherz photographed.

\section{THE FRESCOES IN SUPERPOSITION}

Maack saw three successive levels of frescoes; a prolonged study of the painted panel permitted me to see more, probably eleven. The succession of the details is sometimes uncertain.

Series 1 is composed of big black figures, generally very faded and of miserable art - often mere shapeless debris; there are only six human forms, one indeterminate pachyderm, and a seal (?) which are legible. Their early date is very obvious.

Series 2. Small yellow line-drawings only a few traces remain, earlier than the following series; which they rather resemble:

Series 3. Various small, very simple, rather light red figures, 14 people; 7 small buck; 2 or 3 wading birds:

Series 4. Fourteen small black persons; no better than the preceding series.

Series 5. More or less deep red-brown figures, resembles series : 3 , but shows areater concern for details; the figures are less active. There are only four of them.

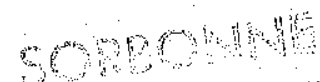

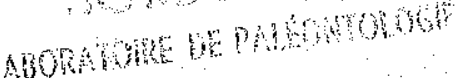


Series 6. Wide animal figures, the contours drawn with a thin red line, perhaps originally filled in with white; there is only a rhinoceros and the belly contour of a grazing animal. The art is excellent and shows a precision of drawing very superior to what preceded it. There is a sense of volume, lacking before.

The relative order of the three following series is doubtful.

Series 7 ? White and black figures: three fairly small persons and a wildebeest in excellent style.

Series 8? White figures: one ostrich, 1 cheetah, 3 persons. (their silhouette and carriage is excellent), 1 person with an antelope head-perhaps the first version of the man afterwards changed to a baboon and loaded with ornaments in the 11th series. This series is a great advance on the five first ones.

Series 9?. Medium sized figures, brown, brown-red and red, in a good style suggesting the beautiful later development; there are 6 persons.

Series 10. Polychrome figures with a white background; 6 humans; the skeleton-spirit of the upper frieze; the zebra. It may be that part of the human figures indicated are less old than Series 11, and should be included in it.

Series 11. The polychromes, the most spectacular element of this palimpsest, are parts of a whole - a symbolical ceremonial procession. A study of the figures composing it shows it was executed at various times by varied artists, each having a different palette and ideas, leading them to retouch the pre-existing paintings and modify several times the racial type, e.g., surcharging a negro profile on a European face. The scene shown in Series 11. includes animals, men and mixed beings.

Animals: The most recent animal is a dark coloured eland. Most of the animals are oryx (gemsbok) forming a continuous line of 6 specimens in the upper frieze. Another similar band formed part of the lower register, but these have mostly disappeared. There is still one springbok in good condition and a fine hartebeest certainly of the same age, but towards the foot there are older traces of a frieze of springbok. Polychrome giraffes and ostriches do not appear . Pon look down (bike the The series in this shelter therefore does whole of the pictorial elements in this region. The oryx with their bi-chromatic foundation show the same technique which, used mostly on elands, ${ }^{5}$ characterizes the culminating period in the art of the South-East province (on two slopes of the Drakensberg). We know nothing similar in Rhodesia or Tanganyika. The absence of elephants and carnivorous animals should also be noted.

Mixed Figures. This is not a case (as in most of the Bushman paintings) of masked men with animal heads, but of animals with human legs, probably genii or more or less spirit-beings. There are three: an antelope with eurved horns (sable antelope?) whose four legs are human arms and legs. An oryx, very well drawn, but with crupper and legs forming human hind-quarters (above the Lady), a Hartebeest with human hind-legs, probably rather more recent than the normal animal placed above.
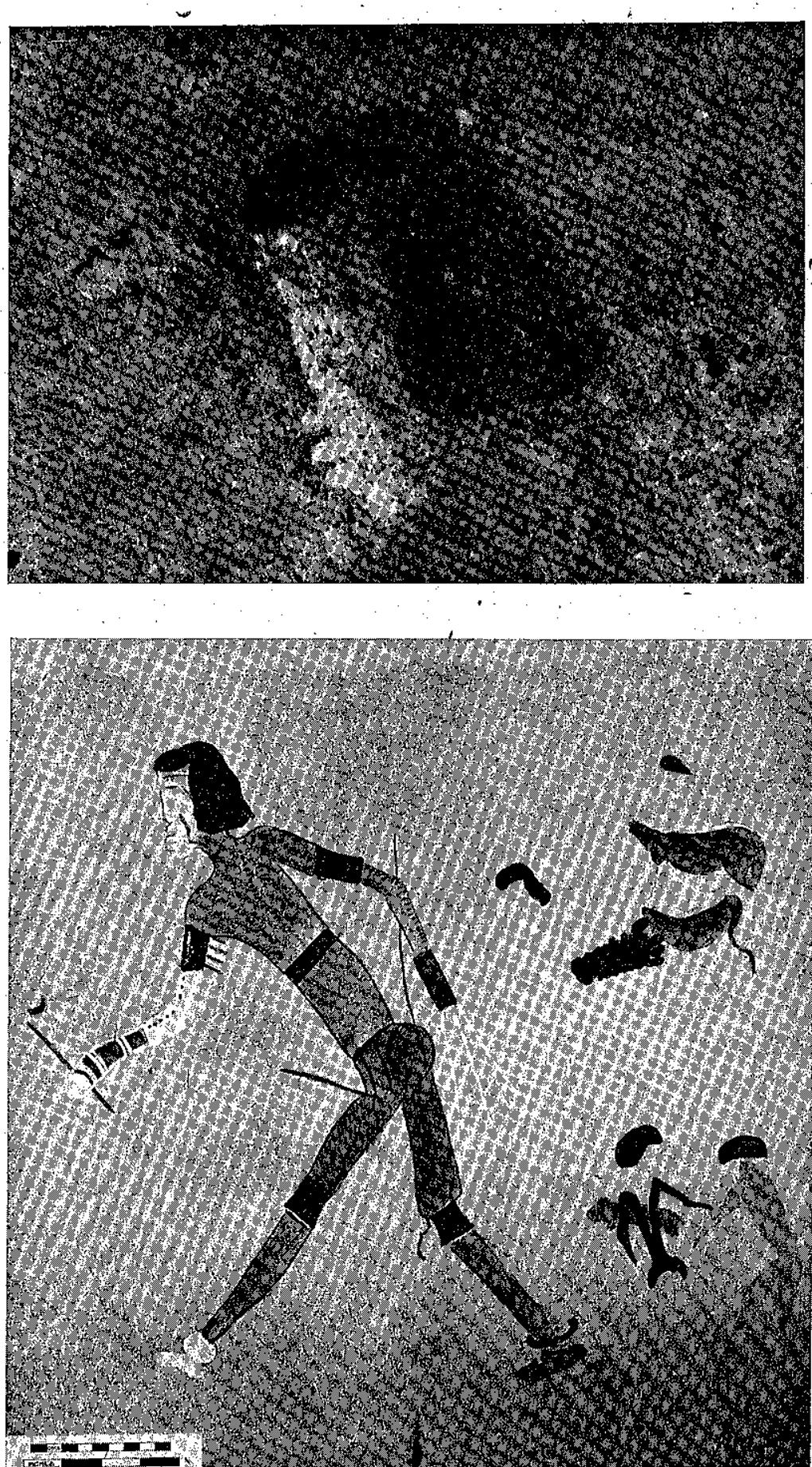

Plate I.-The last figure in the Brandberg frieze. The " European" nose has had Negroid features added below. Above, photo from the actual rocks; below, photo from a tracing 
Animal Masks. The only one certainly forming part of the procession and painted all at once, is the man with a crocodile's head, coming almost at the head of the procession. His mask has two oryx horns and an enormous ear fixed towards the back, and fixed to a large funnel upside down (a basketwork?); the whole fits round the shoulders

The white man, later transformed into a baboon by the addition of a muzzle and a bent tail, forms also part of the procession, and was given, also at a later date, red white-beaded bands; but his is an older figure annexed later for the procession.

Another added stranger is the small person with a jackal head, who appears to be arrested by two others of the normal type of those taking part in the procession.

Human Figures. There are twenty-eight, including the crocodile-man, who walk in this procession, and five outside it. They are; from left to right: two musicians playing the musical bow and greeting the cortege; a third musician, also turned to the right, playing a winid instrument, behind the fifth person marching to the left. A rather steatopygous woman heads the march in this direction, she carries a split stick. Behind her comes the crocodile-man, holding behind him a strung bow and some arrows; he is surcharged by another person with no attributes carrying a $\mathrm{Y}$-shaped stick. Behind him is a youth with red-brown skin, with many ornaments, holding behind him two strung bows and two arrows, and in front two leaf-shaped "daggers" (?). Behind him comes the fourth musician carrying two longer weapons like these; reniains of the frieze beneath show that there must have been more musicians (?) turning to the right.

A little lower down on the right there is a dark man with a horned head and a long, pointed nose, carrying a small broom in front of him, and behind two long pointed knives. He is superimposed on a zebra and another faded white figure, and lifts a hand to his face, carrying behind him a bow and a bundle of arrows.

Then, in the centre of the sheiter come the four principal persons and the human-legged oryx. In front come two youths, the highest one, reddish brown in colour, is not a woman as could be supposed, since the left hand is slung across the chest taking the shape of a breast, but his sex is indicated. His forehead with very accentuated brow-ridge and the coup-de-hâche at the root of his nose, and other facial characteristics, give him an Australoid appearance: Lower down, a third lad; brownish-black, looks most. Eoyptian, as is his garment with beaded hands across his chest, he holds a small bow and arrow in front and two swords like skewers behind. Like the crocodile-man he is infibulated.

\section{THE WHITE LADY}

Then comes the "White Lady", after some scattered remains of an effaced figure. She is walking quickly to the left, holding in front of her face either a cup or a big white flower, and in her left hand held behind her, a strung bow with arrows (one at the ready) and a sheaf of three more. Rosy-white from her waist to. her feet, she wears a clinging garment rather dark-coloured from her waist to her neck, with short sleeves and several beaded bánds, such as her companions wear, at knees, hips, waist and wrists. Like several of her neighbours she has various objects stuck into her armlets. The face is very delicately painted and has nothing native about it. All the white part of her costume is streaked with red, somewhat like the white streaking all over the body and legs of the second youth. ${ }^{6}$ She is shod, as are all those of her companions previously described, unless the painting of their feet has been effaced.

Hugo Obermaier, led astray by Mack's bad drawings, inverted the sex of the two chief figures in the procession; but Lawrence Green the writer, in one of his books where he mentions the Brandberg, speaks of a visit to the "White Lady". The three neighbouring figures, three of those who precede them and several others, are certainly masculine and several of them infibulated. It seems to me that, though her breasts are not more marked than those of the person following her, there can be no doubt about the sex of the "White Lady". We shall discuss hes type of head later.

\section{OTHER FIGURES}

Behind her, and also striding along, comes an uncanny figure dressed in dark colours, he is the tallest of all; on his face is painted in white a lower jaw with teeth, and an eye-socket. His nose is snub. It is a skull, and this impression is accentuated by a black band deeply incurved at the loins which seems to represent the spinal column. The "harness" round his bust is like that worn by the Egyptian youth and he is much adorned with beaded bands round his arms, legs and body. The masculine organ is infibulated. His hat like that of the third musician has a spotted bird's wing in it; his gauntlets - and only his - have black studs; his right arm outstretched behind the "White Lady", holds a long shaft studded with triangular teeth, the end being covered by the painting of the Lady; the bow she holds is also superposed; which argues in favour of her having been repainted; as $I$ suggest. In his left hand stretched out behind, he holds two daggers and two heart-shaped fans (?).

Almost touching these last two objects are two young people with red hair, running; the second wears beads on the hair and lower body; they are painted in the deep rose shade mentioned, which, in the White Lady, is overlaid with white. They wear ornaments, on the chest, showing at an opening, and round the neck; this rose colour therefore represents a clinging garment and not flesh. They are superposed on a big. black very faded figures, and near two black and white human figures. The top one may have had his red hair added later and his two neighbours may have originally started by being like him and had their legs lengthened later.

On a higher register there are three red-brown smaller figures, perhaps dancers, walking in single file. The second is masculine and the third shorter and squarer, probably femine; they carry nothing visible, but are superposed on the remains of a faded polychrome man lying'on his back; his head is hidden by the middie foung dancer, and his legs are trodden on by the feet of the third. The ong line visible must be the string of his bow of which the wooden part (panted white) has faded. 

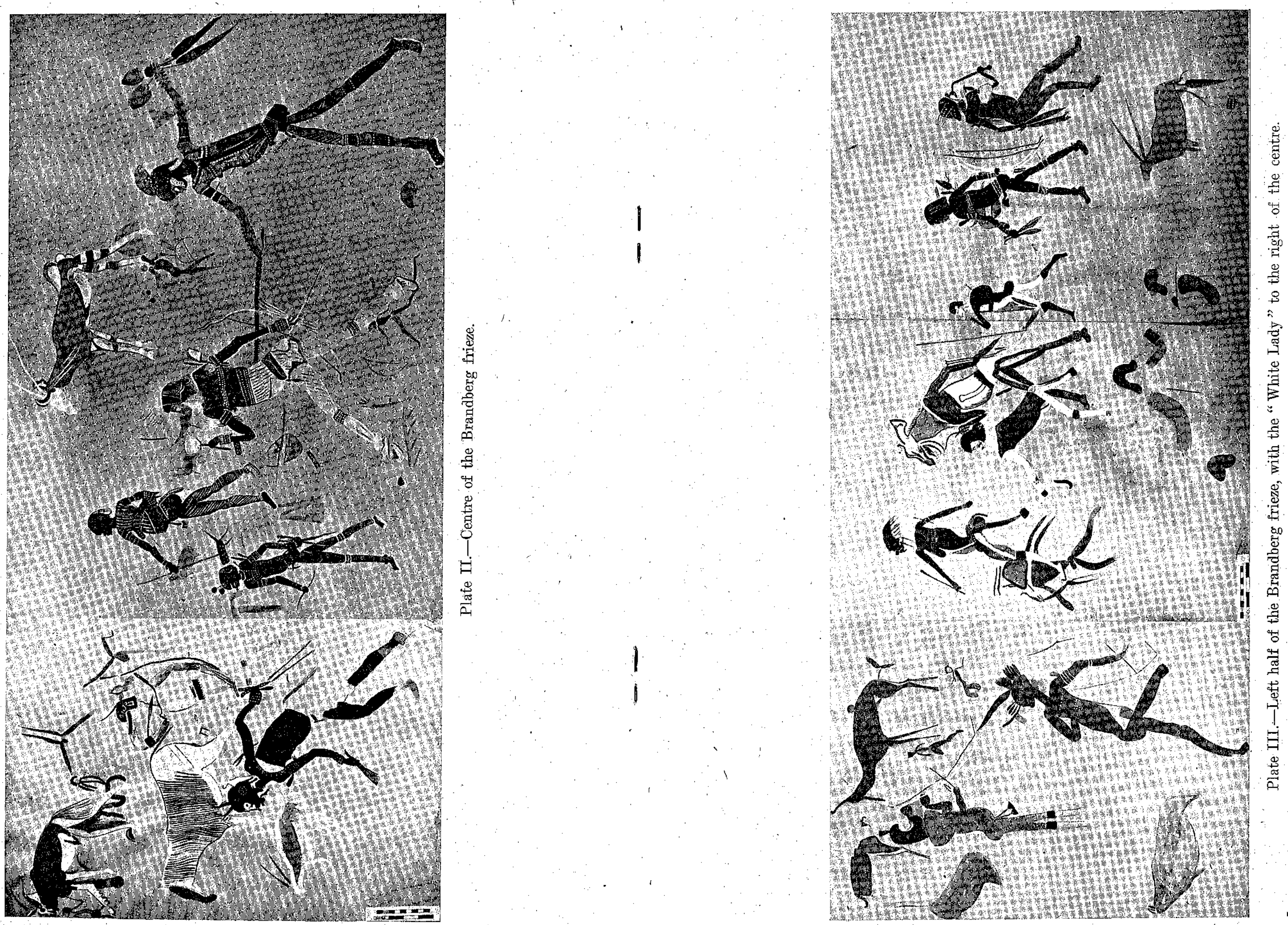
A little lower on the left is the Baboon-Man who I think: was repainted several times, and who is wielding a bull-roarer. Behind him is a bow-string, the whitepainted wood of the bow having almost vanished. His left arm is deformed and too small and the hand grasps a stiletto stuck in his belt. His red hair is decorated with white globules or flowers.

To the right of all these less important figures; we find two more extremely interesting examples.

A fourth youth, standing still, looking tired, is superposed on a bichrome springbok. His right arm, very badly painted in white, seems to have been added later to his very well drawn dark-coloured silhouette. His face is certainly African, but neither Bushman, nor Hottentot. He wears various beaded bands on his chest, arms, loins, knees and ankles and heavy shoes; and along his left arm lies an object similar to the one held to his face by the partly faded archer near the zebra.

The last big figure strides to the left. His pale pink elinging garment is striped with short lines, he wears the usual arm and knee bands and girdle. His face was originally "European". The straight forehead and long narrow nose had their lower half later painted over with a negro mask, with a thick flat nose, projecting lips and receding chin. I think also that the outstretched right arm was repainted at the same time.

i

The tail of the procession consists of small and medium-sized figures, mostly painted in white, but all have red hair and the same beaded bands. There is an archer carrying a big bow and a sheaf of arrows, but there are no quivers.

The last man in the procession wears a dark-coloured robe and is older than the white archers nearby. He is waving a small sceptre, his nose is long and straight and his hair red. He is not African. The shoes on both feet are visible but at some more modern date an additional leg has been added, sticking forwards across his neighbour.

We must also mention two small red-haired people; one, also dressed in a robe, appearing to arrest the person with the jackal mask.

\section{RACIAL TYPES}

Such are the chief polychrome figures of the eleventh series. Let us study them a little more: The racial types are mixed; six are certainly not natives, but Europeans or Mediterraneans, themselves of mixed types; several are fair, others olive or even darker skinned. There are five definitely black, two of which are repaintings of an original face of another type; one is Australoid. None are either Bushman or Hottentot. Most of these people (2\% in all, if we include figures of which the head is the only part preserved) have red hair cut as a fringe in front; others have hair like a wig or a head-dress in helmet shape, either like a Roman helmet or the "tin hats" of modern wars."

We cannot explain this mixture of races except by a column or better still a ship's company of foreigners, settling in the country for some time, or returning on several trips, and camping amongst the rocks near the fresh water spring. My opinion is that a mixed band of foreigners, recruited when they started forth, in the course of their journeyings added to their company negro helpers also foreign to the region, some of whom are painted here, and that they brought with them beliefs much as are found in Egypt and Crete, and an artistic gift, inspired probably by these civilisations.

That history tells us little of the very ancient voyages and of only two voyages round the continent, is true; but I am not convinced that its documentation is complete, or that it provides an exhaustive knowledge of the doings and efforts of non-official explorers.

It would be tedious to cite the very numerous times that companies of people of various races are seen in Cretan or Egyptian art, both in processions of their own peoples, or of their vanquished enemies. In any case, the characteristics mentioned are foreign to all native races. On the "Girls' School" rock, bodies frankly steatopygous carry. heads with "hair" cut in the same style, but yet longer; while the figure of a white woman on the island is just the same, though she wears a very tall vertical blood-red probably cylindrical mitre.

\section{CLOTHING}

Most, if not all the people, in this procession are dressed in closely-clinging costumes with chest-bands, belts, arm, elbow, wrist, knee, ankle-bands and girdles; several wear a gauntlet on the right wrist, no doubt to do with their archery.

The third youth and the Skeleton: Man wear a sort of harness round their busts, which is clearly Egyptian - especially the beaded "braces". The Lady's costume is obviously Cretan, all embroidered in beads like the ones on her hair. Sometimes the upper opening of the garments is indicated and is edged by coloured bands; at other times it is triangular, and covers the top part of the chest.

Several wear some sort of leggings, and with others their tights end in a roll round the ankle. In several the garment covering the torso and arms is separate from that covering the trunk and legs. All those with painting of the feet still' preserved, and painted in sufficient detail, wear a moccasin type of shoe.

\section{MUSICAL INSTRUMENTS AND WEAPONS}

As regards the musical instruments, there are two musical bows definitely African; this instrument with variations is known from the Bushmen to the Zulus The bull-roarer is also in general use. The wind instrument of the third musician has not been determined.

Bows and arrows are borne by only nine people in the procession. The fact that the "White Lady" is the best armed of all, and the only one with an" arrow at the ready, tends to support other reasons for thinking that she may be the Diana-Isis known in Crete and Egypt, as some elaborate research by Miss Boyle seems to have established. The Brandberg bow is far more convex than that of Rhodesia, and nearer to those of South-Eastern Africa. Those painted are of medium size except for the very small one carried by the third youth. The Egyptian bow varies in shape; but a sinuous type frequent in Egypt and probably. Asiatic in origin; is absent here.

No one in this procession carries a quiver; nor apparently is it found in Rhodesia, but it is extremely frequent in South-Eastern Africa - either cylindrical 
and small, or with a handle amongst the natives, Bushmen, and other pre-Bantu. peoples, or big and very wide when carried by the "foreigners" (not the same foreigners as in the Brandberg and S. Rhodesia). The quiver was not in general use in Egypt. The kings had them (or rather bow-cases) holding both bows and arrows, fixed to their chariots, and the ordinary large quiver was carried in Mesopotamia. The bands of archers very seldom carried them:

The arrows (we are not sure that they were feathered) had a $Y$-base and a movable end with poisoned tips, the "Diana" has a reserve of these in her right arm-band.

\section{CURIOUS OBJECTS}

An object whose use is uncertain, of variable shape and size, the long stem painted red, sometimes reduced to the size of a small rod, and edged with white spots or strokes all round (fur or feathers?) is carried by seven of the group, including "Diana". It is usually stuck in the arm-band, sometimes in the wristlet. The faded archer behind the zebra lifts one to his face as if to wipe away the sweat and dust, as suggested to us by Dr. Jeffreys. The term strigil, borrowed from the Roman world, might be applied to it.

Other pointed objects generally carried in pairs, may be daggers, knives, or swords, and are always held point downwards. ${ }^{8}$. The first lad has two leaf-shaped ones with long stems, curling back at the end like a metal tang, flattened by hammering; this is repeated on another example painted alone in the lower register; all three resemble the Cyprian type of dagger, well known in Egypt and used by most of the Mediterranean peoples.

The third musician holds two in her lowered right hand, one resembles the pistil-shaped bronze swords, the other has a double-lobed tip. The Crocodile-man in his left hand holds a blade, like a wide rippling knife, as well as his bow and arrows.

The left hand of the Skeleton-man also holds two blades like big straight knives, similar to those often reproduced, also in pairs, in Egyptian frescoes. But the pair of what look like skewers (held in the left hand of the third lad, 'and by the black-horned man in the lower register) have obvious hilts, one pair buttonshaped, the second pair incurved. They also hold them point downwards; so were held (according to Miss Boyle's researches) the weapons carried by the "Men of Horus" when hunting the Crocodile god of evil in Egypt, their weapons pointed. earthwards.

We must also note the floral element introduced several times in our fresco; a little flower with white petals and red heart between the lips of the third youth (the Egyptian), the globules or buds adorning the cap of the Baboon-man, of the Egyptian youth and the last " tired" lad. Similar globules; often in pairs, are frequent in Rhodesian paintings.

If the white cup-like object held by "Diana" to her face is a flower, it can be compared to others similar held in the same position by Cretan or Egyptian ladies, or it may be an ostrich-shell cup. This cannot be definitely decided. ${ }^{9}$
We must also note the kind of tuft, or little plant with leaves or roots, held in the left hand of the small European person in a robe at the end of the procession.

Such o-

plychrome fresco of the Maack shelter.

Many problems are suggested, which can only be solved by fresh research and more discoveries.

The scene is certainly a kind of ceremonial symbolical ballet; as had been suspected by my much regretted friend $\mathrm{H}$. Obermaier, though he had only imperfect and incomplete copies to judge by. It argues a direct or indirect foreign influence, perhaps even the hand of a foreign artist. Frobenius and Fraulein Weyersberg had suggested a Mesopotamian influence; I do not think they were right. Miss Boyle and I are more inclined to look to Crete and Egypt. In any case it is not a direct or single influence, but a close blending of various elements, some African, but not local, and others Mediterranean, Egyptian and Cretan.

Anyhow, as it is recognized that Egyptian civilisation, though it received material and spiritual gifts from Asia and Crete, yet had its roots firmly planted in the depths of black Africa, it is reasonable to search in this magnificent flower of art from the African stem for the clue to some of the problems we have suggested. ${ }^{10}$

\section{REFERENCES}

1 Some of this information I owe to Dr. Martin, one of our guides and now a member of the Irrigation Department of the Province.

2 The big indurated shale gravels show many signs of the most remarkable mechanical peudo-trimming made by the violence of the torrent. I have seen nothin like it.

3 A rapid excavation made by Dr. Martin, revealed two levels; the lower contained only quartz tools, probably late Middle Stone Age, and the upper was rich in thousands of indurated shale chips (workshop rubbish) and Smithfield A tools.

4 But the insolation of the rocks during the daytime makes the shelters very comfortable at night, when they give out the accumulated heat. On the plain the nights were -very chlly in August, when we were there, but in the ravine there was only a very sharp cold breeze which came up from below lasting usually only a quarter of an hour.

They were painted during a long period, in pre-Bantu times, except som

degenerate types.
$6 \mathrm{I} \mathrm{am}$. inclined to think that the rosy-white part of her body has been repainted in white on a deep rose ground immediately beneath, the same shade as that of two small figures following the skeleton man.

i $\mathrm{I}$ know the Ovambo Ombalantu women arrange their hair in helmet shape, adding to it, I think, plats of vegetable hbre and col tion with cow dung.

It has also been suggested that they are zebra tails used as fly-whisks; we record this though thinking it improbable.

A fragme of an anted

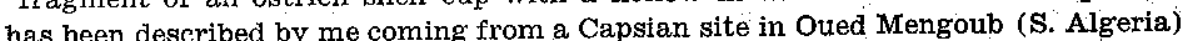
10 We are indested to 